\title{
Switching from Post-paid to Pre-paid Models: \\ Customer Perception and the Organisational Role in Managing the Change: A Case Study of Botswana Power Corporation
}

\author{
Mburu P. T \\ Senior Lecturer and Head, Department of Marketing \\ Faculty of Business, University of Botswana, Gaborone, Botswana \\ Sathyamoorthi C.R. \\ Associate Professor and Dean, Faculty of Business \\ University of Botswana, Gaborone, Botswana \\ Received: June 23, 2014 Accepted: July 8, $2014 \quad$ Published: July 8, 2014 \\ doi:10.5296/jmr.v6i3.5858 ～URL: http://dx.doi.org/10.5296/jmr.v6i3.5858
}

\begin{abstract}
This case study examined the perceptions of the consumers after the switch over from post-paid to pre-paid electricity billing model by Botswana Power Corporation and at different parameters that measure the satisfaction of customers on the utility service provided by service providers. The study also focused on customer perception on how the Botswana Power Corporation managed the change with a view to see whether the overall satisfaction had increased or decreased. A non-probability type of sampling was used and questionnaires were used as data collection instrument. The findings indicate that the customers have embraced the pre-paid billing system and that they have recognized the benefits of conversion to the pre-paid model. The positive perception on the prepaid system requires that the Botswana Power Corporation should make certain that quality service, better network, and regular check on the meters are carried out to ensure that the positive perception is maintained at the highest level. It is also recommended that in future, consumers are consulted and changes communicated to them in good time to address any possible negative perception about the change. Such a move will also ensure easy customer buying-in to the changes.
\end{abstract}

Keywords: Post-paid, pre-paid, Customer satisfaction, Customer Perception, Pricing Perception, Safety Perception, Billing Model, Change Management 


\section{Introduction}

The payments of utility bill in Africa have been on postpaid model over the years. In recent years however, most municipalities and utility cooperation's are changing to prepaid models, in order to cash on the benefits by the model (Harvey, 2005). Income to municipalities and utility corporations is dependent on trust between the state and the individual household. The monthly or quarterly cycle of billing is an expression of a mutual obligation and trust resulting into the provision of services preceding the payment. However, this trust is often betrayed by customers who miss to pay the bills or not pay on time for various regions. Municipalities and utility corporations have an obligation to inscribe in the technology with which a social contract, entailing the assumption of a regularized flow of provision and payment where by citizenry is both willing and able to pay (Von Schnitzler, 2008). The prepaid models have become popular with many municipalities, especially while targeting the poor for the provision of water, electricity, telecommunication, health services among others (Harvey, 2005). The adoption of the prepaid models has the potential of ensuring constant supply at lower cost, despite of the political and social dimension (Soto, 2012, ). A well-managed model results into customer satisfaction and positive perception of the organization as well-received services. Some researchers however see the introduction of prepaid models as capitalistic management of the poor (Ruiters, 2009, Tewari, 2003, Bond, 2007). Bond, (2007) noted that in some cases the customer are not consulted when the changes to prepaid models are effected (Bond, 2007, Baptista, 2013). Despite the good intensions, lack of consultation leads to customers not buying-in into the changes and thus bad perception of services and poor customers satisfaction. Customer satisfaction is the state of mind emanating from position customers have about a company that their expectations of service meet or exceed by the product or service. In order for organisation to meet or exceed customer expectation, introduction of innovations becomes necessary. Innovation can be introduced either radically or incrementally. Incremental innovation is driven by a customer's desire for an improved product or service, which enhances performance and convenience, while radical innovation is economic and technologically driven by organisations desire to be ahead of competitors (Vercauteren, 2008). Introduction of innovation should be envisaged to provide positive perception, being perceived as an incremental innovation, which is customer-driven rather than radical innovation, which is technology-driven (Wijmans, 2001, O’Connor, 2001)

\section{Objectives}

Customer satisfaction emanate from positioning of a company when customers perceive guarantee that their expectations would be met or exceeded by the product or service. "Satisfaction" itself can refer to a number of different facets in the relationship with a customer (Oh, 1999). Satisfaction refers to the quality of a particular product or service, the process, an on-going business relationship, the price-performance of a product/ service or as a result or a product/service meeting or exceeded the customer's expectations. In today's unpredictable business environment, it is natural to argue that the central task of any management is to manage the change. An organization is expected to formulate an overall change strategy, particularly one that has overall synergy with an organization's business strategies, especially 
where the change has a potential to affect the customer perception on its products. The success of any project is dependent on how well the change is managed. The objectives of the study therefore were:

1. To investigate consumers' perceptions after the switching from post-paid to pre-paid electricity billing model, looking at the different parameters that measure utility service satisfaction by the customers.

2. To gauge how well customers perceived the organisation managing the change, in order to see if the overall satisfaction has increased or decreased.

The study would inform other utilities corporations and municipalities on benefits of prepaid models and the possible drawbacks that could be avoided.

\section{Prepaid Models in Africa}

Electricity meters in Africa have dominantly been electromechanical in nature. However many countries like Tanzania, South Africa, Ghana among others, have introduced sophisticated and accurate digital and electronic meters. A prepaid energy meter enables power utilities to collect power bills from the consumers before usage of power thereby lowering the percentage of electricity revenue lost to power theft, incorrect meter reading and billing, and reluctance and inability of consumers to pay electricity bills on time (Jain, 2011). The application of prepaid energy meter, results into a considerable savings, increased revenue, reduction of losses, efficiency, and overall profitability (Khan, 2010, O’Connor, 2001).

Pre-paid electricity requires customer to pay upfront before electricity can be consumed. Electricity consumption is controlled with a pre-paid electricity meter, which is usually mounted or installed in or outside the house (Subramoney, 2007).The meter must have credit loaded before electricity can be consumed. The meter will interrupt the electricity once the credit or units have been depleted.

The customer will purchase electricity at the nearest electricity vendor. The vending of electricity tokens, or vouchers, not only widens the access appoints for the provider, but creates entrepreneurs and business opportunities, thus employment. The electricity is purchased as a monetary value encoded as a kilowatt-hour $(\mathrm{KWH})$ value in tokens or codes or vouchers. The meter credit register is only updated once the code is inserted and accepted by the consumer's meter.

Baptista (2013) noted that pre-paid electricity gives consumers autonomy of electricity use and divisibility of energy purchases. Pre-paid model facilitates forms of sociability and social ordering that are not only exclusively economic, but also political, familiar and technological. In Mozambique, the peri-urban dwellers welcomed pre-paid electricity model since they felt empowered (Baptista, 2013). Tewari D. D., (2003) and , Baptista, (2013) concurred that energy specialists, economists and development scholars are generally positive about benefits of pre-paid model to both consumers and utility producers. 
Through pre-paid model, consumers can easily monitor and thereby manage their budget, and by so doing reduce unnecessary and wasteful use of electricity such as non-economizing on lights, and appliances being left turned on (Tewari D. D., 2003). There are both advantages and disadvantages of pre-paid model on both the consumers and the utility providers. In theory, pre-paid system through the In-Home Displays (IHD) can revolutionize the way utility organisations communicate information to customers by inducing changes in customer behaviour even when they are not accompanied by a change in electric prices or rebates for purchasing efficient equipment. IHD provides consumers with direct feedback-real-time information on energy consumption and costs. It turns a once opaque and static electric bill into a transparent, dynamic, and controllable process (Faruqui, 2010). Pre-paid system benefits the municipalities and utility corporations by improving its profits, reducing consumers' bad debts associated with post-paid and thus improved customer relations (Harvey, 2005). Another often-overlooked advantage for utilities is the safety of the corporation's employees. Meter readers who are always expected to frequent consumer's residences to do meter reading, predispose themselves to dangers like dog biting, weather hazards, underlings, among others, as well as perception of intrusion in customers' privacy (Jain, 2011) .

\section{History of Botswana Power Corporation}

Botswana Power Corporation (BPC), a Parastatal utility that was formed in 1970 by an Act of Parliament is responsible for the generation, transmission and distribution of electricity within Botswana to areas approved by the Ministry of Minerals, Energy and Water Resources. The Corporation, within the forty-one years of its existence, has developed from a small, oil-fired power station in Gaborone, which was commissioned in 1970 and dismantled in 1989 to one Thermal Power Station at Morupule situated some twelve kilometres west of Palapye village in the Central District. The Power station is supplied with coal from adjacent Morupule Colliery.

\section{Prepaid Electricity model in Botswana}

Botswana Power Corporation has a mandate of supplying electricity to the nation, both in the rural and in the urban centres. Electricity has been supplied to the rural and urban areas using the post-paid model of supply over the years. During the periods 2001 to 2003, the government of Botswana embarked on a project of electrifying 15 villages with the intention of bringing services to the nation. On the same period, Botswana Power Corporation (BPC) introduced relaxed payment terms for its customers with the hope of increasing its customer base. Customers had to pay 5\% deposit upfront and the deferred balance was repayable on instalments of 18 months with no interest, 60 months at an interest of prime less than $0.5 \%$ and finally 180 months at prime interest rate. In 2006/2007, a contract was signed with Swedish company to electrify 100 villages in 36 months. For the same period, government funded electrification for 30 villages. Furthermore, in 2010 after the completion of the electrification of 100 villages, a National Electricity Standard Cost (NESC) was introduced in rural areas. The connection cost was reduced to P5000.00 (about US\$ 580) as long as the household's distance from the existing electricity network line is within 500m radius. 


\section{Ml Macrothink}

Relaxed payment terms were also applied to NESC customers at a minimum deposit of 5\% plus an additional 12\% VAT, the balance was then be to paid in instalments of 6 months at prime interest rate less $6 \% ; 12$ months at prime interest rate minus $4.5 \%$ and 18 months at prime interest rate minus $2 \%$. In 2011, NESC was also introduced in urban areas with the same conditions as those of rural areas. These projects increased accessibility of electricity to customers. However, they posed a serious challenge to BPC because the demand for electricity increased as well as customers' expectations to have electricity in their households. Currently BPC has segmented its customers as under:

Table 1: BPC customer base per type of use

\begin{tabular}{|l|l|}
\hline Type of customer & $\begin{array}{l}\text { Number of } \\
\text { customers }\end{array}$ \\
\hline Water pumps & 278 \\
\hline Government building & 5040 \\
\hline Domestic & 298989 \\
\hline Small business & 17878 \\
\hline Medium business & 2198 \\
\hline Large business & 367 \\
\hline Mine & 10 \\
\hline
\end{tabular}

- Source: Sebudubudu K., University of Botswana (2013), Pp15

The prepaid models targeted the domestic market segment that consume low units per capita and are numerous. The administration of these accounts translates to lower margins for BPC compared to other segments such as mines.

\section{Switching from post-paid to pre-paid models in Botswana}

In 2011, a decision was taken to convert urban areas electricity from post-paid to pre-paid form. The decision was taken by the corporation as a way of mitigating the complaints from the customers, about receiving over-estimated bills or at times not even receiving the bills at all. The Botswana cooperation introduced several platforms of purchase of pre-paid electricity as a way of easing the accessibility of electricity procurement. These included Purchase of electricity through point of sales, Cell phone banking, ATM's, Internet, E-Wallet, and Scratch cards sold through supermarkets and other retail vendors. This conversion was envisaged not only to benefit consumers, but the corporation as well in helping cut the costs which were related to post-paid. These costs included the cost of bill processing, printing, and posting as well other costs related to accounts management. The company's profit would improve as the post-paid system allowed the company to be owed or lose millions of Pulas through consumers' bad debt practices. 


\section{Theoretical framework}

While undertaking any change in an organisation, three steps of unfreezing, moving, and refreezing are necessary as proposed in the Lewin's theory of Change management (Levasseur, 2001).

This maximises the acceptance rate while minimizing the barriers to change opportunities and provided the opportunities to bring out positive gains by the change. While Lewin's three-step theory worked on the internal change management, (Miyogo,et al 2013), the same theory is equally applicable while dealing with customers who are used to receiving services offered by an organisation like BPC, which enjoys monopoly in electricity service provision.

Customer relations managers as change agents are expected to communicate the new system actively with all customers in the unfreezing step. They are expected to assure the commitment of the organisational value it places on customers, and the necessity to maintain and improve its services to better heights. Customers expect to access electricity and pay at the end of the month after receiving the bill. Wrong billing, lack of bill or delayed bills create anxiety in customers' mind and affects the company's positioning. Thus, the organisation should strive to ensure undisrupted supply and communicate timely accurate bills. This simple three-step model explains the importance of implementing successful change by unfreezing the existing situation followed by change movement and making the new behaviours and norms absolute. By applying such a concept of dynamic stability, an organization might look forward to a successful outcome in change implementation. The primary communication objective of the unfreezing stage should be to prepare customers to anticipate the change. This has been called "readying" the organization, and the research results are clear concerning the wisdom of such preparation (Miyogo, et al 2013).

According to Miyogo, et al (2013), if the change is more than marginally incremental, it is likely that resistance, some of it quite strong, will surface because old values and methods are implicitly challenged. Some resistance will remain underground while it is gathering strength. During the refreezing stage, the first thing to do is to communicate the need for a change by providing a specific rationale such as a discrepancy between necessary outcomes and actual outcomes or an opportunity that captured through change.

As noted by Miyogo, et al (2013), the change theory is applicable to any change management, especially to corporation changing from one model of customer service provision to another. The change from post-paid to prepaid model necessitates a requisite change management by BPC to ensure the process transited smoothly from unfreezing the customer's mind-set from expecting a bill at the end of the month. At the same time they need to inform what the change entails, detailing all the aspects of the new model. After the change is done, they need to freeze the customers mind set.

\section{Importance of perception in change management}

Different researchers have viewed the adoption of the prepaid models differently. While some see it as a provision of freedom to consumers, (Wijmans, 2001, Faruqui, 2010) and a potential of ensuring constant supply of electricity at lower cost, some have seen it as way 


\section{Ml Macrothink}

Journal of Management Research

ISSN 1941-899X

2014, Vol. 6, No. 3

of capitalism gaining on the poor masses (McDonald, 2009, Bond, 2007, Soto, 2012, ). The importance customer perception management is therefore necessary to ensure proper positioning of the corporations or municipalities' intentions in changing to prepaid models, thereby providing customer buy-ins, satisfaction and positive perception of the organization as well services (McDonald, 2009). According to Hocutt (1997), perception of service equity affects consumer satisfaction and complaint behaviour (Brown, 1984, Bitner, 1990). The foundations of equity are based on perceptions of justice (Greenberg 1996); distributive justice that focuses on the perceived fairness of the outcome on the service encounter and interactional justice that focuses on the perceived fairness on the manner in which the customer is treated throughout the service encounter. When change is effected, irrespective of how beneficial it is, without express permission of customers, the client-customer's relationship is dented and in some cases, trust is lost.

\section{Drivers of Customers Perception in prepaid model}

According to (Alam, 2012) several factors affect the perception of customers on prepaid meters acceptance or non-acceptance. These factors are organisationally manageable before and after the installation of prepaid meters. These factors include:

Table 1: Drivers of customer perception on prepaid acceptance or non-acceptance

\begin{tabular}{|c|c|}
\hline Cost of electricity with prepaid meters & Does it lower or make higher the cost of electricity \\
\hline Fairness & $\begin{array}{l}\text { Do customers feel well treated or neglected by the } \\
\text { company as a result of change }\end{array}$ \\
\hline Location & Location of meters and their accessibility \\
\hline Health and Safety & How safe the prepaid meters are to the family members \\
\hline Access to the prepaid units & $\begin{array}{l}\text { Access to tokens or vouchers where needed, and the } \\
\text { ability of uploading it to meters, ensuring there is no } \\
\text { online downtime. }\end{array}$ \\
\hline Reliability of prepaid meters & $\begin{array}{l}\text { Guarantee that the units loaded would be equal to what is } \\
\text { consumed and there will be no pilferage }\end{array}$ \\
\hline User friendliness of prepaid meters & $\begin{array}{l}\text { How easy it to load the meters at any variant of } \\
\text { environment }\end{array}$ \\
\hline Durability of prepaid meters & $\begin{array}{l}\text { Guarantee on how long the meter last before replacement } \\
\text { and or repairs; who is supposed to do repairs the meters } \\
\text { and how to access these services }\end{array}$ \\
\hline Accessing to prepaid vending points & $\begin{array}{l}\text { How accessible is the units in multiples that a consumer } \\
\text { can afford when they require them and at the most } \\
\text { convenient time and place }\end{array}$ \\
\hline Cost of installation of prepaid meters & Who bears the cost of installation and repair of meters \\
\hline $\begin{array}{l}\text { Availability of technicians to repair faults of } \\
\text { prepaid meters }\end{array}$ & $\begin{array}{l}\text { How available would be the technical support to assist in } \\
\text { time of need by the consumers and how knowledgeable } \\
\text { are the technicians. }\end{array}$ \\
\hline Customer benefits & $\begin{array}{l}\text { Who benefits more from the whole process, and what do } \\
\text { I get as a customer from the whole change experience }\end{array}$ \\
\hline
\end{tabular}


Prepaid electricity has great opportunities, if well managed, and there is a possibility of losing those benefits if not well administered. In Bangladesh, the system was initiated as a pilot project but because of some loophole, the customers did not perceive it as a better option, in spite of significant benefits (Alam, 2012). With proper measures taken to reduce the drawbacks of the system, it can contribute to the consumer's continence and country's economy in many ways. It is therefore necessary to take effective measures, which would ensure that customers consider the prepaid electricity system as the better option for household electricity consumption.

\section{Organisation role in managing customer expectations and perception}

Service encounter form an essential element of product perception. According to Kelley and Davis, (1994) change management must determine both what customers expect and how they expect to get it. Management must plan, implement and control the service offering to limit, reduce, or eliminate service quality gaps. Service quality perceptions are sums of various facets such as responsiveness to customers, reliability, assurance, and tangibles among others (Boulding et al 1993). All of these are essential in the conversion of electricity products from post-paid to pre-paid models. Customers should have an assurance that the later services will be better and reliable, safer as well as ensuring better response in case of a problem. This is essential given the fact that the normal monthly contact with staff is highly curtailed. The service quality literature by (Babakus and Boller, 1992; Cronin and Taylor, 1992; Parasuraman et al. 1985; 1988; 1991; Zeithaml et al. 1988) on how service quality perceptions are construed, defines the dimensions of service quality as consisting of functional, managerial and technical quality. Parasuraman et al. (1988) definition dominates the literature. Zeithaml et al. (1988) define perceived service quality as the difference between consumer expectations and their perceptions resulting from the degree and direction of five gaps occurring in the internal process of service delivery. The Power Corporations and Municipalities have an obligation to ensure that customer views are looped in, fears addressed, better service assured and all stakeholders and organisational perception synchronised when managing the transition from post-paid to pre-paid models thus ensuring perceived service quality. The lack of literature in Botswana regarding the above change management necessitated this study.

\section{Data collection methods}

The study used both quantitative and qualitative approaches (Neuman, 2007), focusing on customers who had their power metres converted from post-paid to pre-paid within the past six months as from December 2013. This was to ensure that the respondents could compare both services with an educate opinion. The researchers used an exploratory type of research with 5 points Likert scale questionnaire and personal in-depth interviews with randomly selected respondents. 


\section{Macrothink}

Journal of Management Research

ISSN 1941-899X

2014, Vol. 6, No. 3

\section{Sampling scheme}

The target population for this study was adult individuals who stay in electrified households whose electricity has recently been converted from post-paid to pre-paid model. The researchers used a non-probability type of sampling, as it is convenient and economical.

The participants included those:

- Adult individual either a male or a female who reside in an electrified house that has recently been converted from post-paid to pre-paid.

- Residing in Gaborone city and its environs

- Those who are utilizing one of the platforms of purchasing pre- paid electricity from the prescribed service point

- Who were willing to participate in the study

\section{Findings and Discussion}

The researchers got 223 fully completed and usable questionnaires, of which 107 were male and 116 female respondents. Of these, about $70 \%$ had tertiary education and $27.3 \%$ had secondary education. About $73 \%$ of the above resided in Gaborone city while $27 \%$ resided in the peri-urban areas all of which had conversion to prepaid electricity in the last one year. The $82 \%$ of the respondents were employed and about $12 \%$ were self-employed. This had an implication on respondents doing end of the month purchase of electricity or at least a monthly recharge.

Table 2: Demographics ( $\mathbf{N = 2 2 3 )}$

\begin{tabular}{|l|l|}
\hline VARIABLE & FREQUENCY \\
\hline Gender & \\
\hline Male & $107(48 \%)$ \\
\hline Female & $116(52 \%)$ \\
\hline Age & \\
\hline $21-35$ & $82(36.8 \%)$ \\
\hline $36-50$ & $127(56.9 \%)$ \\
\hline Above 50 & $14(6.3 \%)$ \\
\hline & \\
\hline Highest Education Level & \\
\hline Primary & $6(2.6 \%)$ \\
\hline Secondary & $61(27.3 \%)$ \\
\hline Tertiary & $156(70 \%)$ \\
\hline Residence & \\
\hline Gaborone & $163(73.3 \%)$ \\
\hline Greater Gaborone & $60(26.7 \%)$ \\
\hline
\end{tabular}


The study shows that participants utilized more than one vendor to purchase electricity vouchers or tokens. Of the six vendors that were identified, retailer/ supermarkets was the most preferred vendor (76\%). Respondents reported that it was convenient for them as they would buy electricity whilst they were buying their groceries. $48 \%$ of the respondents preferred to get the recharge vouchers from the BPC outlets. Those who utilized the BPC outlet were of the view that electricity units bought directly from BPC outlet were cheaper and thus got more units per pula amount compared to other vendors. About $25 \%$ of the respondents bought from mobile phone recharge citing convenience while $21 \%$ used ATMs. Tuck-shops and post office had the least preference with less than $10 \%$ in each case.

Less than one-half of the respondents indicated that electricity had become expensive, indicating that most customers viewed electricity cost as remaining the same or reducing. However, this was not a unified voice looking at the standard deviation of 3.7; the opinion was much diversified and inconclusive.

Table 3: Perceptions of Prepaid Model

\begin{tabular}{|c|c|c|}
\hline GENERAL PERCEPTIONS & Mean & Std. Deviation \\
\hline Electricity has become expensive & 1.9067 & 3.67897 \\
\hline I believe the conversion was a good move & 4.6667 & .72968 \\
\hline Capitalist move to enrich big corporations & 1.8400 & 1.29054 \\
\hline The system is disadvantageous to the poor & 1.3667 & .99944 \\
\hline I was never consulted before the conversion & 2.6133 & 1.01808 \\
\hline The electricity bill is higher than before & 1.6133 & 1.06681 \\
\hline There is guarantee as who would repair the meter if damaged & 2.9933 & 1.13218 \\
\hline There is a probability of electricity pilferage & 2.2067 & 1.04462 \\
\hline It is not clear on how the electricity price was arrived at & 2.0667 & 1.24602 \\
\hline Convenience & Mean & Std. Deviation \\
\hline Perception of prepaid system (convenient) & 4.7533 & .73216 \\
\hline Can buy with affordable amount & 4.8667 & .55159 \\
\hline Somebody can buy me units and send them & 4.9000 & .52775 \\
\hline The minimum limit is not convenient for me & 1.4000 & .95538 \\
\hline I am able to budget for my electricity & 4.8200 & .62466 \\
\hline It is easy to access pre-paid units & 3.8000 & 1.31588 \\
\hline THE NETWORK availability & Mean & Std. Deviation \\
\hline The network is not always available when need to recharge & 2.8200 & 1.33648 \\
\hline PRICING PERCEPTIONS & Mean & Std. Deviation \\
\hline Different vendor sell the units at different price( it is not uniform) & 2.2667 & 1.25140 \\
\hline $\begin{array}{l}\text { There is a significant difference in price/unit regarding buying of } \\
\text { pre-paid units at different times of the month }\end{array}$ & 2.2533 & 1.17117 \\
\hline
\end{tabular}




\begin{tabular}{|l|l|l|}
\hline SAFETY PERCEPTIONS & Mean & Std. Deviation \\
\hline \hline $\begin{array}{l}\text { it is dangerous to the family especially to kids when trying to } \\
\text { replenish units }\end{array}$ & 1.5333 & 1.09708 \\
\hline $\begin{array}{l}\text { There are instances of tampering with meter because of its outside } \\
\text { positioning }\end{array}$ & 1.8243 & 1.19930 \\
\hline & & \\
\hline
\end{tabular}

Majority of the respondents perceived conversion to be a good move for them with a mean of 4.66 supports and at the same time, they perceived the move as not disadvantageous to the poor. However there seemed to be no agreement as to whether the conversion had made electricity cost to be either cheaper or more expensive. Those interviewed also indicated that they were not informed or consulted on the conversion with a mean of 2.6 indicating they were never consulted. Although there was no consultation, majority of the responded assumed that the Botswana power Corporation would repair the meter if damaged while 2.2 indicated that they feared the probability of pilferage of their electricity because of the conversion.

Majority of the respondent supported the conversion due to the convenience it was perceived to bring in, with a mean of 4.6 , while the ability to buy the affordable amount had a mean perception of 4.8. The convenience emanating from the fact that one could budget, buy electricity, and send to the relatives irrespective of the distance had a mean of 4.8 and 4.9 respectively. This indicates the overwhelming support of conversion.

Access to the voucher purchase points was perceived to be convenient enough with a mean of 3.8 though some had difficulties especially with the online purchases due to network failures. Network failure was noted to be a problem with a mean 2.8 noting that they could not recharge when they needed to do so.

The pricing of the vouchers was perceived not to be uniform from all the vendors with a mean of 2.3 perceiving different vendor selling the units at different prices. The tuck-shops were perceived to be more expensive than supermarkets while the Botswana power Corporation outlets were perceived to sell the units at the cheapest rate.

Although some respondents had fear specifically because of the location of the meter box, the perception was not significant with a mean of 1.5. However this differ between male and female with female perceiving it as more dangerous with a mean of 1.6.

The researchers used T-Tests to test for differences in perception between male and female groups on some variables of interest on conversion of electricity from post-paid to pre-paid model. Overall results indicate that females perceived the model more negatively in almost all variables than males, who supported the conversion. 
Table 4: Perceptions of Prepaid Model by gender

\begin{tabular}{|c|c|c|c|c|}
\hline Variables & Mean & & $\mathrm{F}$ &. $\operatorname{sig}$ \\
\hline & Male & Female & & \\
\hline Electricity has become expensive & 1.514 & 2.27 & 2.445 & .120 \\
\hline I believe the conversion was a good move & 4.61 & 4.72 & 2.365 & .126 \\
\hline It is easy to access pre-paid units & 3.76 & 3.83 & .568 & .452 \\
\hline $\begin{array}{l}\text { it is dangerous to the family especially to kids when trying } \\
\text { to replenish units }\end{array}$ & 1.43 & 1.63 & 4.283 & .040 \\
\hline The system is disadvantageous to the poor & 1.29 & 1.44 & 2.295 & .132 \\
\hline Capitalist move to enrich big corporations & 1.64 & 2.03 & 8.470 & .004 \\
\hline
\end{tabular}

Looking at the variables individually, there was no much difference in perceptions in believes that conversion was a good move and easy to access prepaid units. At the same time, the perception of the model being disadvantageous to the poor appears to be insignificant. The above observation is confirmed by the significance (p-value) of .120 .126 .452 and .132 consecutively, all of which are greater than 0.05. On the notion that the new system posed danger towards the family especially kids and the aspect of the corporation enriching itself, the results showed to be significant with the p-values .040 and .004 respectively. This is evident that the females are more concerned about the safety of the family than the males; just as well as they see it as a move by big corporation (BPC) to enriches itself.

\section{Conclusion}

Unlike in the studies by (McDonald, 2009, Bond, 2007, Soto, 2012, ), respondents perceived the benefits of the prepaid to over shadow the drawbacks, since it provided convenience and empowered them in decision-making. Customers noted that they were not consulted before the conversion negated the positive perception. This resulted into the mixed perception on pricing, network availability and underutilization of some electricity-vending outlet. At the same time, the negative perception of safety, benefits to the poor and the enrichment corporation would have been better addressed by pre-conversion education of the consumers.

The benefits of conversion to the prepaid model were well recognised by the respondents as most the respondent perceived conversion to be a good move. However cost of electricity with prepaid model was perceived to be higher and access to the prepaid units though accessible, the online downtime was noted as a problem.

The conversion is quite recent and as such, the quality of the electricity meters could not be tested. However, the respondents assumed that the BPC would service the meters as they had installed them. Although the price was perceived to be fair, there was no agreement since some of the respondent's perceived disparities in price depending on the vendors.

The positive perception on the prepaid system requires that the BPC should ensure that quality service; better network and regular check on the meters is carried out to ensure that a positive perception is maintained at the highest level. The fact that there are fewer interfaces with the BPC staff, there is a possibility of the customer's services department losing the 
customers inputs, thereby compromising on the customer service quality. This could lead to poor perception and should be guarded against. At the same time, the future changes should be well communicated to the customers to correct any possible negative perception and ensure customer buying-in to the changes beforehand.

In conclusion, it is the opinion of the researchers that the findings of this study have insightful implications on customer perception on changes in payment system for utilities in developing countries like Botswana and other developing as well as developed countries. The current study was limited to the customers in and around Gaborone city and the researchers aspire to conduct a more comprehensive study in future that will encompass the towns and villages in Botswana where the prepaid billing system for electricity is implemented. The researchers also believe that such study should cover a longer period (say five years), thereby be able to measure the magnitude of changes in consumer perception on the prepaid billing model over that period.

\section{References}

Alam, J. (2012). Electricity Billing Systems at Residential Level in Sylhet City: Is Pre-Paid System erceived as a Better Option by the Subscribers? Industrial Engineering Letters, 2(3), 45- 61.

Babakus, E., \& Boller, G.W. (1992). An empirical assessment of the SERVQUAL scale. Journal of Business Research, 24, 253-68. http://dx.doi.org/10.1016/0148-2963(92)90022-4

Baptista, I. (2013). Everyday Practices of Prepaid Electricity in Maputo, Mozambique. oxford UK: institute for scince innovation and society .

Bitner, M. B. (1990). The Service Encounter: Diagnosing Favorable and Unfavorable Incidents. Journal of Marketing, 54, 71-84. http://dx.doi.org/10.2307/1252174

Boikanyo, B. (2013). Consumer perception towards conversion of electricity from postpaid to prepaid. Research report; University of Botswana, Gaborone, 19-25

Bond, P. \&. (2007). Decommodifying electricity in postapartheid Johannesburg. Contesting neoliberalism:s. Urban frontiers, 179-203.

Boulding, W, Karla, A, Staelin, R, \& Zeithaml, V.A. (1993) A dynamic process model of service quality: from expectations to behavioural intentions. Journal of Marketing Research, 60(30), 7-27. http://dx.doi.org/10.2307/3172510

Brogowicz, A. A., Delene, L. M., \& Lyth, D. M. (1990). A synthesised service quality model with managerial implications. International Journal of Service Industry Management, 1(1), 27-45. http://dx.doi.org/10.1108/09564239010001640

Brown, S. a. (1984). Consumer Complaining and Word of Mouth Activities: Field Evidence. Adv. in Consumer Research, 16, 9-16. 
Cronin, J.J., \& Taylor, S.A. (1992). Measuring service quality: a re-examination and extension. Journal of Marketing, 56, 55-68.

Faruqui, A. S. (2010). The impact of informational feedback on energy consumption-A survey of the experimental evidence,. Energy, 35(4), 1598-1608.

Greenberg, J. (1996). The Quest For Justice on the Job: Essays and Experiments, Thou-sand Oaks, CA: Sage Publication

Harvey, E. (2005). Managing the poor by remote control: Johannesburg's experiments with prepaid water meters. . The age of commodity: Water privatization in Southern Africa,, 120-127.

Hocutt, M. A. (1997). The impact of perceived justice on customer satisfaction and intention to complain in a service recovery. Advances in consumer research, 24, 457-463.

Jain, A. \&. (2011). A prepaid meter using mobile communication. International Journal of Engineering, Science and Technology, 3(3). http://dx.doi.org/10.4314/ijest.v3i3.68432

Kelley, S. W., \& Davis, M. A. (1994). Antecedents to customer expectations for service recovery. Journal of the Academy of Marketing Science, 22(1), 52-61.

Khan, R. H. (2010). A prepaid smart metering scheme based on wimax prepaid accounting model. Smart Grids and Renewable Energy, 1(2), 63-69. http://dx.doi.org/10.4236/sgre.2010.12010

Levasseur, R. E. (2001). People Skills: Change Management Tools - Lewin’s Change Model. Interfaces, 31(4), 71-73.

McDonald, D. A. (2009). Electric capitalism: Conceptualising electricity and capital accumulation in (South) Africa. ELECTRIC CAPITALISM. London : starling VA.

Miyogo, C., Ondieki S., \& Nashappi N. (2013). An Assessment of the Effect of Prepaid Service Transition in Electricity Bill Payment on KP Customers, a Survey of Kenya Power, West Kenya Kisumu, American International Journal of Contemporary Research, 3(9), 88-96

Neuman, W. L. (2007). Basics of social research: Qualitative and quantitative approaches (2nd ed.). Boston, MA: Pearson Education

O’Connor, G. C. (2001). The nature of market visioning for technology-based radical innovatio. Journal of Product Innovation Management .18(4), 231-246.

Oh, H. (1999). Service quality, customer satisfaction, and customer value: A holistic perspective. International Journal of Hospitality Management, 67-82. http://dx.doi.org/10.1016/S0278-4319(98)00047-4

Parasuraman, A., Zeithaml, V.A., \& Berry, L.L. (1985). A conceptual model of service quality: its implications for future research. Journal of Marketing, 49(4), .41-50. http://dx.doi.org/10.2307/1251430 
Parasuraman, A., Zeithaml, V.A., \& Berry, L.L. (1988). SERVQUAL: a multiple-item scale for measuring consumer perceptions of service quality. Journal of Retailing, 64(1), .12-40.

Parasuraman, A., Zeithaml, V.A., \& Berry, L.L. (1991) Refinement and Reassessment of the SERVQUAL Scale. Journal of Retailing, 67, 420-450.

Parasuraman, A., Berry, L. L., \& Zeithaml, V. A. (1993). More on improving service quality

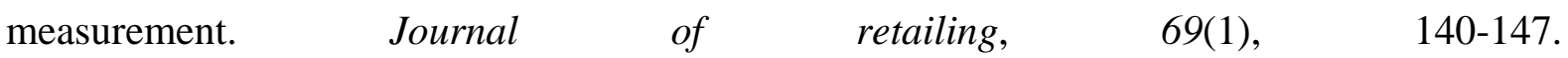
http://dx.doi.org/10.1016/S0022-4359(05)80007-7

Ruiters, G. (2009). Free basic electricity in South Africa: A strategy for helping or containing the poor. Electric Capitalism:Recolonising Africa on the Power Grid. London,: Earthscan.

Sebudubudu K. (2013). An Evaluation of Customer Service Delivery in a Public Enterprise of a Developing Country: The Case Study Of The Botswana Power Corporation (BPC); MBA desperation, University of Botswana 2013: PP 15

Soto, D. A.-S. (2012). A prepaid architecture for solar electricity delivery in rural areas. Johanesburg: Routledge. http://dx.doi.org/10.1145/2160673.2160691

Subramoney, G. H. (2007). A Secure Web Service for Electricity prepayment and industry Specification Vending in South Africa: A Case Study;. Second international conference on Internet and Web Applications and Services (ICIW'07). Morne, Mauritius. http://dx.doi.org/10.1109/ICIW.2007.9

Tewari, D. D. (2003). An assessment of South African prepaid electricity experiment, lessons learned, and their policy implications for developing countrie. Energy Policy, 31(9), 911-927. http://dx.doi.org/10.1016/S0301-4215(02)00227-6

Vercauteren, A. (2008). Customer/supplier interaction for radical technological innovation: inhibitor or facilitator? Belgium: Hasselt; https://doclib.uhasselt.be/dspace/bitstream/1942/8563/1/IMP08\%20Conference.pdf, Department of Business Administration.

Von Schnitzler, A. (2008). Citizenship Prepaid: Water, Calculability, and Techno-Politics in South Africa . Journal of Southern African Studies,, 34(4), 899-917. http://dx.doi.org/10.1080/03057070802456821

Wijmans, H. (2001). Creating New Products" in Jakki Mohr Marketing of High-Technology Products and Innovation. New Jersey pp 175-176: Prentice Hall .

Zeithaml, V.A. (1988). Consumer perceptions of price, quality, and value: a means-end model and synthesis of evidence. Journal of Marketing Research, 52, 2-22. http://dx.doi.org/10.2307/1251446

Zeithaml, V.A, L.L Berry, \& A Parasuraman. (1996). The behavioural consequences of service quality. Journal of marketing, 60, 31-46. http://dx.doi.org/10.2307/1251929 